\title{
SUITABILITY OF MEDIUM DENSITY PARTICLEBOARD FROM ACACIA CATECHU AND MELIA DUBIA
}

\author{
Sharma $S^{1, *, N e g i} A^{2}$, Behera $J^{3} \&$ Naryal $R^{4}$ \\ ${ }^{1}$ Wood Science and Technology (Composite Wood), Forest Research Institute (FRI), Dehradun 248006, Uttarakhand, \\ India \\ ${ }^{2}$ Indian Council of Forestry Research and Education (ICFRE), Dehradun 248006, India \\ ${ }^{3}$ Silviculture and Agroforestry, Nauni 173230, Solan, Himachal Pradesh, India \\ ${ }^{4}$ Wood Science and Technology (Composite Wood), Forest Research Institute (FRI), Dehradun 248006, Uttarakhand, India \\ *saurabhsharma8312@rediffmail.com
}

Received May 2020; accepted October 2020

\begin{abstract}
Forest resources and tree stock in different countries decline rapidly due to the rising population. Rapid wood consumption created a major wood stock shortage. There is also an immense disparity between demand and supply. Particleboard provides the opportunity to use the greatest possible volume of forest resources and industrial waste. The main objective of this study was to evaluate the physical-mechanical properties of particleboards made from kattha extracted particles of Acacia catechu and Melia dubia. Boards were prepared from different ratio of particles of $A$. catechu and M. dubia i.e. 50:50 and 60:40 at two different pressures of $17.5 \mathrm{~kg} \mathrm{~cm}^{-2}$ and $21 \mathrm{~kg} \mathrm{~cm}^{-2}$ using 10 and $12 \%$ resin content. Their physical properties (moisture content, density, water absorption, general swelling and thickness swelling) and mechanical properties [modulus of rupture (MOR), modulus of elasticity (MOE) and screw withdrawal strength] were evaluated. The best experimental results were obtained by mixing particles in the ratio of 50:50 with $12 \%$ resin content at 21 $\mathrm{kg} \mathrm{cm}^{-2}$ specific pressure and $150{ }^{\circ} \mathrm{C}$ temperature for 15 minutes which meets the requirements of medium density particleboard as per Indian standard IS 3087:2005. The utilisation of kattha extracted particles of A. catechu and M. dubia in different combinations and parameters can be explored for the development of wood composites.
\end{abstract}

Keywords: Acacia catechu, Melia dubia, particleboards, kattha, composites

\section{INTRODUCTION}

In India, three main types of wood-based panels viz. plywood including block board, flush door and particleboards are manufactured. There is considerable increase in demand for such products because they have an advantage over solid wood, in addition to their physical and mechanical properties. Particleboard offers a means to utilise the forest and industrial wood waste since it is similar to wood quality and can be obtained from a wide variety of species, both softwood and hardwood. Particleboard manufacturing is sustainable due to abundance of raw materials, manufacturing and product properties. Owing to carbon emission and depleting forest resource within the country, particleboards, as an alternative to solid wood product, will have a huge market in wood-based industries.
The demand for composite wood products, particularly particleboard, has significantly increased owing to their use in construction, cabinets, tabletops, vanities, sliding doors, speakers, table tennis, stair treads, kitchen worktops, laboratories and other industrial products (Alam et al. 2015). Probable causes for the slow growth of particleboard industries in India are marginal R\&D efforts, both in industry and institutional level. The major use of khair, however, is in the production of kattha and cutch (a dyeing and preserving agent) (Tewari 1994). Khair is a valuable economic structural timber, the heartwood being naturally durable. This species has been classified as super group timber suitable for large spans more than $12 \mathrm{~m}$ and is placed as the first choice of selection for permanent structures (ISI 1962). 
The chief constituents of heartwood vary from $4-7 \%$ and are distributed throughout the heartwood from root to branches. This occurs throughout India in dry types of mixed forest on a variety of geological formations and soils. The third article of commerce is also obtained as white powder, known as kheersal, which appears as a deposit in the wood. It is used for medicinal purposes especially for cough and sore throat (Siva 2007). Investigations carried out by Uday et al. (2011) on the suitability of Melia dubia for plywood manufacture have shown that type-B surface veneers could be produced by peeling, and the veneers could be dried without major degrades. Any lignocellulosic material can be used for particleboard manufacturing such as under-utilised wood species (e.g. Acacia catechu and M. dubia).

Nasser (2012) determined the basic properties of $A$. catechu and its suitability as raw material for the manufacture of composite panels. Acacia catechu is a hardwood of high specific gravity with a value of $0.874 \mathrm{~g} \mathrm{~cm}^{-3}$ for 29-year-old trees (Mayuree 1990). The species is distributed in the greater part of India except for the most humid and drier region. There is no report on the use of this species other than for fuel and extraction for katha and cutch (Tewari 1995). It is the main source for catechu (a medicine) and a cutch. The bark of the fastgrowing species Acacia can be used as a powder for making PVC composites, which may find applications as a substitute to high-cost wood and to avoid deforestation. Samples for testing were prepared by compression moulding. Tensile strength and percentage of elongation at break decreased, whereas modulus increased with an increasing amount of bark flour. A significant increase in storage modulus $\left(\mathrm{E}^{\prime}\right)$ was observed upon the incorporation of filler
(Saini et al. 2010). Better board properties were obtained with the addition of $2 \%$ aluminum sulphate or magnesium chloride at lower wood/ cement ratio of 1:2.5. (Rahim-Sudin and WanAsma-Ibrahim 1990).

In general, all the species under investigation can be used in the particleboard industry if they are pressed at a density level of $750 \mathrm{~kg} \mathrm{~m}^{-3}$, while their dimensional stability properties might be improved by additional treatments, such as coating surfaces with melamine-impregnated papers or laminates to achieve a more stable product (Hegazy and Aref 2010). Investigations were carried out by Prakash et al. (2017) in which lops and tops of M. dubia from plywood manufacturing facility were converted into wood particles which were later used to manufacture particleboard. Boards produced were tested as per IS 3087:2005 (Iwakiri et al. 2012), studying the production of homogeneous and multilayer particleboard from M. azedarach (cinamomo) and Pinus taeda with different resin contents. Particleboard offers a means to utilise mixed plantation species because it is similar to wood quality and comprises a wide variety of species. The study carried out by Choudhary et al. (2015) mainly focused on evaluating the physical and mechanical properties of particleboard prepared from admixtures of Populus deltoides and M. composita at different proportion levels and resin contents, at $17.5 \mathrm{~kg}$ $\mathrm{cm}^{-2}$ specific pressures as per Indian Standard Specification (IS 2380-1977).

\section{MATERIALS AND METHODS}

\section{Particle preparation}

Particles were prepared from dark wood chips of A. catechu (khair) and M. dubia (melia). They were used for particle preparation:

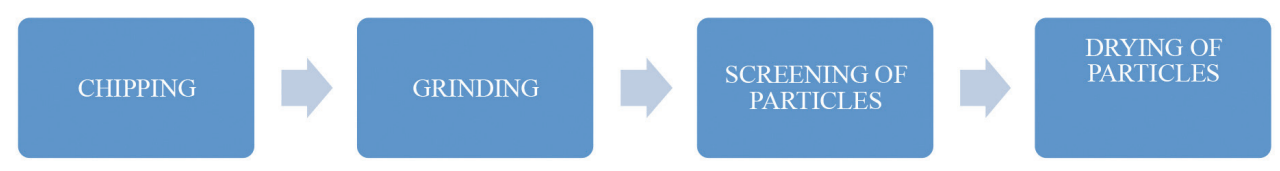




\section{Preparation of resin}

\section{Preparation of phenol-formaldehyde resin}

Three bottles of phenol were heated in a boiling water bath. Then, $2500 \mathrm{gm}$ of phenol with 3000 $\mathrm{ml}$ of formalin and $3000 \mathrm{ml}$ of water was added to the flask. The $\mathrm{pH}$ of the whole solution was maintained at $9-9.5$ by adding $125 \mathrm{gm}$ of sodium hydroxide flakes dissolved in 150 $\mathrm{ml}$ of water. The round flask with solution was mounted on a boiling water bath and observed until reaction started. The actual reaction started when the first bubbling was seen in the solution. The solution was refluxed for 30 minutes. The resin was cooled for 24 hours. The cooled resin was analysed for various contents and parameters.

\section{Analysis of resin}

Six tests were performed to obtain data regarding various parameters of the resin produced. The tests are as follows.

\section{Solid content of the resin}

The amount of solid resin present in $100 \mathrm{ml}$ of the resin solution was calculated by the following formula:

$$
\text { Solid content } \%=\frac{\text { Weight of solid resin }}{\text { weight of liquid resin }} \times 100
$$

\section{Ash content of the resin}

Ash content is the amount of inorganic material present in $100 \mathrm{gm}$ of the solid resin. It is expressed in percent and calculated as follows:

$$
\text { Ash content }(\%)=\frac{\text { Weight of ash }}{\text { weight of solid resin }} \times 100
$$

\section{Water tolerance}

Water tolerance is the volume of water required to precipitate a certain amount of resin.

$$
\text { Water tolerance of the resin }=\frac{\mathrm{V}_{2}}{\mathrm{~V}_{1}}
$$

$p H$

$\mathrm{pH}$ was measured using $\mathrm{pH}$ indicator paper and found to be 10 .

\section{Flow time}

Flow time was measured with the help of the ford cup viscometer. It is the time taken by the resin to pass through the ford cup. It is measured in terms of seconds. The flow time of water was found to be 11.15 seconds and that of resin was 15.79 seconds.

\section{Viscosity}

The viscosity of a fluid is a measure of its resistance to gradual deformation by shear or tensile stress. Viscosity is measured by a viscometer.

\section{Specific gravity}

Specific gravity is the ratio of the density of a substance, i.e. resin, to the density of a reference substance, i.e. water. It is calculated by taking the weight of resin and water in the relative density (RD) bottle. It is calculated as follows:

$$
\begin{aligned}
& \text { The specific } \\
& \text { gravity of resin }
\end{aligned}=\frac{\text { Weight of resin }}{\text { weight of water }} \times 100
$$

\section{Amount of resin required per board}

For $10 \%$ of resin content:

$$
10 \% \text { of } 2000 \mathrm{gm} \text { material }=\frac{10}{100}=200 \mathrm{gm}
$$

Since the solid content in the resin prepared is $35 \%$, the amount of resin required per board is:

$$
\text { Weight of resin }=\frac{200 \times 100}{35.04}=570.77 \mathrm{gm}
$$

For $12 \%$ of resin content:

$$
12 \% \text { of } 2000 \mathrm{gm} \text { material }=\frac{12}{100} \times 2000=240 \mathrm{gm}
$$


Since solid content in the resin prepared is $35 \%$, the amount of resin required per board is:

$$
\text { Weight of resin }=\frac{240 \times 100}{35.04}=684.93 \mathrm{gm}
$$

\section{Resin blending}

About $2000 \mathrm{gm}$ of dried particles were collected for particleboards; $25 \mathrm{gm}$ extra was collected because some material gets wasted during the blending process. The amount of resin added was $5 \mathrm{gm}$. The resin was coated on the particle in a rotary blender by spraying at pressure 100 lbs in ${ }^{-2}$. Resin blending was carried out 8 times for every board.

\section{Drying}

The resin blended particles were then air-dried to attain a moisture content of $6-8 \%$. The resin blended particles were then uniformly spread on long aluminium sheets for 24 hours after blending. This allows particles to be properly dried before being used in the mat formation process.

\section{Mat formation}

The entire caul plates were heated up in a hot press and wax was applied. Then a wooden frame $\left(2^{\prime \prime} \times 21\right.$ ") was placed on them. The resin blended particles were uniformly laid to form a mat in the wooden frame and were levelled from periphery to central portion. Te particles were manually pre-pressed by using a levelled wooden board for 2 minutes, and the wooden frame was taken out. Another caul plate with wax application was placed over the mat. The mat in between two caul plates was then kept in the press.

\section{Hot pressing}

The mats were pressed in a hot press at pressures $17.5 \mathrm{~kg} \mathrm{~cm}^{-2}$ and $21 \mathrm{~kg} \mathrm{~cm}^{-2}$ and pre-fixed at temperature $150{ }^{\circ} \mathrm{C}$ for 15 minutes.

\section{Conditioning}

After removing the particleboards from the hot press, they were allowed to condition at ambient room temperature and humidity for 2 days, before sampling. The boards were stacked one over another, and a weight was placed on the whole stack for 2 days.

\section{Indian standards of particle boards}

The minimum requirement of particleboards for various physical and mechanical properties is shown below in Table 1 .

Table 1 Minimum requirement according to IS 3087:2005

\begin{tabular}{|c|c|c|}
\hline Board number & Properties & Flat pressed single layer \\
\hline 1 & Density variation $(\%)$ & \pm 10 \\
\hline \multirow[t]{3}{*}{2} & Water absorption $(\%)$ & \\
\hline & - $2 \mathrm{~h}$ soaking & 25 \\
\hline & - 24 h soaking & 50 \\
\hline \multirow[t]{3}{*}{3} & Linear expansion (swelling in water), $2 \mathrm{~h}$ soaking (\%) & \\
\hline & - Length & 0.5 \\
\hline & - Width & 0.5 \\
\hline 4 & Thickness swelling (\%), 2 h soaking & 10 \\
\hline 5 & Swelling in thickness due to surface absorption (\%) & 9 \\
\hline \multirow[t]{3}{*}{6} & Modulus of rupture, $\mathrm{N} \mathrm{mm}^{-2}$ & \\
\hline & - Average & 11 \\
\hline & - Minimum & 10 \\
\hline \multirow[t]{3}{*}{7} & Modulus of elasticity, $\mathrm{N} \mathrm{mm}^{-2}$ & \\
\hline & - Average & 2000 \\
\hline & - Minimum & 1800 \\
\hline \multirow[t]{3}{*}{8} & Tensile strength perpendicular to surface, $\mathrm{N} \mathrm{mm}^{-2}$ & \\
\hline & - Up to $20 \mathrm{~mm}$ thickness & 0.8 \\
\hline & - Above $20 \mathrm{~mm}$ thickness & 0.8 \\
\hline \multirow[t]{3}{*}{9} & Screw withdrawal strength, $N$ & \\
\hline & - Face & 1250 \\
\hline & - Edge (foe thickness $>12 \mathrm{~mm}$ ) & 850 \\
\hline
\end{tabular}




\section{Preparation of test specimen from each board}

The number and size of each test specimen of the medium density particleboard for various tests is described below (Table 2). The specimen dimension, according to IS 3087:2005, is also described below (Table 2). The details of the boards prepared are shown in below (Table 3 ).

\section{Methods of testing the board}

\section{The moisture content of the board}

The moisture content, expressed as a percentage of the oven-dry mass is derived by the formula:

$$
\text { Moisture content }(\%)=\frac{M_{1}-M_{0}}{M_{0}} \times 100
$$

where $\mathrm{M}_{1}$ = initial mass, $\mathrm{M}_{0}=$ oven dry mass

\section{The density of the board}

$$
\text { Density }=\frac{\text { Mass of test specimen }(\mathrm{gm})}{\text { Length } \times \text { width } \times \text { thickness }}
$$

\section{Water absorption}

The amount of water absorbed by each test specimen after 2 and 24 hours was calculated as follows:

$$
\text { Water absorption }(\%)=\frac{M_{1}-M_{0}}{M_{0}} \times 100
$$

where $\mathrm{M}_{1}=$ initial mass of test specimen before submersion, $\mathrm{M}_{0}=$ final mass of test specimen after submersion

\section{Swelling due to general absorption}

The average values of thickness, length and width were obtained from the differences, expressed as a percentage of the original average thickness, length and width, as below:

$$
\begin{aligned}
& \text { Swellingin thickness }(\%)=\frac{\mathrm{T}_{0}-\mathrm{T}_{1}}{\mathrm{~T}_{1}} \times 100 \\
& \text { Swelling in length } \%=\frac{\mathrm{L}_{0}-\mathrm{L}_{1}}{\mathrm{~L}_{1}} \times 100 \\
& \text { Swelling in width } \%=\frac{\mathrm{W}_{0}-\mathrm{W}_{1}}{\mathrm{~W}_{1}} \times 100
\end{aligned}
$$

Table 2 Specimen dimension

\begin{tabular}{ccccl}
\hline $\begin{array}{c}\text { Board } \\
\text { number }\end{array}$ & Parameters & $\begin{array}{c}\text { Number of } \\
\text { specimens from } \\
\text { each board }\end{array}$ & $\begin{array}{c}\text { Size of each test } \\
\text { specimen }\end{array}$ & IS standards \\
\hline 1 & Density & 2 & $150 \mathrm{~mm} \times 75 \mathrm{~mm}$ & IS 2380:1977 (part III) \\
2 & Moisture content & 2 & $150 \mathrm{~mm} \times 75 \mathrm{~mm}$ & IS 2380:1977 (part III) \\
3 & Water absorption & 2 & $100 \mathrm{~mm} \times 200 \mathrm{~mm}$ & IS 2380:1977 (part XVI) \\
4 & General swelling & 2 & $150 \mathrm{~mm} \times 75 \mathrm{~mm}$ & IS 2380:1977 (part XVII) \\
5 & Surface swelling & 2 & $150 \mathrm{~mm} \times 75 \mathrm{~mm}$ & IS 2380:1977 (part XVII) \\
6 & MOR and MOE & 2 & $24 \times$ thickness $+50 \mathrm{~mm}$ & IS 2380:1977 (part IV) \\
7 & Screw withdrawal resistance & 1 & $150 \mathrm{~mm} \times 75 \mathrm{~mm}$ & IS 2380:1977 (part XIV) \\
8 & Internal bonding test & 2 & $50 \mathrm{~mm} \times 50 \mathrm{~mm}$ & IS 2380:1977 (part XIV) \\
\hline
\end{tabular}

$\mathrm{MOR}=$ modulus of rupture, $\mathrm{MOE}=$ modulus of elasticity

Table 3 Details of the particleboards

\begin{tabular}{cccc}
\hline Board number & $\begin{array}{c}\text { Ratio } \\
\text { (Acacia catechu: Melia dubia) }\end{array}$ & Pressure used & Resin content \\
\hline 1 & $50: 50$ & $21 \mathrm{~kg} \mathrm{~cm}^{-2}$ & $10 \%$ \\
2 & $50: 50$ & $21 \mathrm{~kg} \mathrm{~cm}^{-2}$ & $12 \%$ \\
3 & $60: 40$ & $21 \mathrm{~kg} \mathrm{~cm}^{-2}$ & $10 \%$ \\
4 & $60: 40$ & $21 \mathrm{~kg} \mathrm{~cm}^{-2}$ & $12 \%$ \\
5 & $50: 50$ & $17.5 \mathrm{~kg} \mathrm{~cm}^{-2}$ & $10 \%$ \\
6 & $50: 50$ & $17.5 \mathrm{~kg} \mathrm{~cm}^{-2}$ & $12 \%$ \\
7 & $60: 40$ & $17.5 \mathrm{~kg} \mathrm{~cm}^{-2}$ & $12 \%$ \\
8 & $60: 40$ & $17.5 \mathrm{~kg} \mathrm{~cm}^{-2}$ & $10 \%$ \\
\hline
\end{tabular}


where $\mathrm{T}_{1}=$ average thickness before the experiment, $\mathrm{T}_{0}=$ average thickness after the experiment, $\mathrm{L}_{1}=$ length before experiment, $\mathrm{L}_{0}=$ length after experiment, $\mathrm{W}_{1}=$ width before the experiment, $\mathrm{W}_{0}=$ width after the experiment

\section{Swelling due to surface absorption}

The average values of thickness, length and width were obtained from the differences, expressed as a percentage of the original average thickness, length and width, as below:

$$
\text { Swelling in thickness }(\%)=\frac{\mathrm{T}_{0}-\mathrm{T}_{1}}{\mathrm{~T}_{1}} \times 100
$$

where $\mathrm{T}_{1}=$ average thickness before the experiment, $\mathrm{T}_{0}=$ average thickness after the experiment

\section{Static bending test (modulus of rupture)}

Size of specimen

Length $=24$ times of the thickness of the board $+50 \mathrm{~mm}$, width $=5 \mathrm{~mm}$ thickness to less than $6 \mathrm{~mm}$ or above $6 \mathrm{~mm}$ thickness to $75 \mathrm{~mm}$, thickness $=$ full thickness of the board. The length, width and thickness were measured to an accuracy of not less than $\pm 0.3 \%$.

\section{Span and support}

The span (center to center distance between supports) for each test was 24 times of nominal thickness. The support was such that no appreciable crushing of the specimen could occur during the test. The support could be either rounded or knife edged, with rollers and plates under the specimen.

\section{Rate of loading}

Load was applied continuously throughout the test at a uniform rate of motion of the movable crosshead of the testing machine, and calculated by the following formula:

$$
\mathrm{N}=\mathrm{ZL}^{2} / 6 \mathrm{t}
$$

where $\mathrm{N}=$ rate of loading in $\mathrm{cm} / \mathrm{min}, \mathrm{Z}=$ unit rate of fibre strain of outer fibre length/minute $=0.005, \mathrm{~L}=\operatorname{span}$ in $\mathrm{cm}, \mathrm{t}=$ thickness of the specimen in $\mathrm{cm}$

\section{Calculation}

The modulus of rupture was calculated for each specimen, as follows:

$$
\mathrm{N}=3 \mathrm{PL} / 2 \mathrm{bd}^{2}
$$

where $\mathrm{MOR}=$ modulus of rupture, $\mathrm{P}=$ load in $\mathrm{kg}$, $\mathrm{b}=$ width of the specimen in $\mathrm{mm}, \mathrm{L}=$ span length in $\mathrm{mm}, \mathrm{d}=$ thickness of the specimen in $\mathrm{mm}$

\section{Tensile strength perpendicular to the surface (internal bonding test)}

The maximum load was determined from which the stress at failure was calculated for each specimen. Tensile strength perpendicular to the surface was calculated by the formula below:

\begin{tabular}{lc}
$\begin{array}{l}\text { Tensile } \\
\text { strenght } \\
\text { perpendicular } \\
\text { to the surface } \\
\left(\mathrm{N} \mathrm{mm}^{-2}\right)\end{array}$ & Load in $\mathrm{kg} \times 9.8$ \\
\cline { 2 - 2 } & Area of the specimen \\
& in $\mathrm{mm}^{2}$
\end{tabular}

\section{Test for screw withdrawal resistance}

The specimen holding fixture was attached to the lower platen of the testing machine. The specimen was inserted in the fixture, which is equipped with a slot for easy engagement of the screw head, attached to the upper platen of the testing machine.

\section{Statistical analysis}

The entire data generated from the present investigation were subjected to statistical analysis in accordance with Gomez and Gomez (1984).

\section{RESULTS AND DISCUSSION}

\section{Physical properties}

The values of various physical properties i.e. moisture content and density, water absorption, swelling percent and swelling due to surface absorption of particleboards from A. catechu $+M$. dubia, with different pressures, and with $10 \%$ and $12 \%$ resin content are shown below in Table 4, 5, 6 and 7 respectively. In these tables, 1 to 8 are board numbers, and $A$ and $B$ are replications. The values were calculated as per IS specifications. 
Table 4 Moisture content and density of particleboards from Acacia catechu + Melia dubia at different resin content and pressure

\begin{tabular}{|c|c|c|c|c|c|c|c|c|}
\hline $\begin{array}{c}\text { Board } \\
\text { number }\end{array}$ & $\begin{array}{l}\text { Sample } \\
\text { number }\end{array}$ & $\begin{array}{c}\text { Initial } \\
\text { weight } \\
\mathrm{M}_{\mathrm{i}}(\mathrm{gm})\end{array}$ & $\begin{array}{c}\text { Oven dry } \\
\text { weight } \\
M_{o}(\mathrm{gm})\end{array}$ & $\begin{array}{c}\text { Moisture } \\
\text { content } \\
\%\end{array}$ & $\begin{array}{c}\text { Moisture } \\
\text { content } \\
\text { average \% }\end{array}$ & $\begin{array}{c}\text { Volume } \\
\left(\mathrm{cm}^{3}\right)\end{array}$ & $\begin{array}{l}\text { Density } \\
\left(\mathrm{g} \mathrm{cm}^{-3}\right)\end{array}$ & $\begin{array}{l}\text { Density } \\
\text { average }\end{array}$ \\
\hline 1 & $\begin{array}{l}\text { A } \\
\text { B }\end{array}$ & $\begin{array}{l}87.98 \\
83.75\end{array}$ & $\begin{array}{l}83.75 \\
79.35\end{array}$ & $\begin{array}{l}5.05 \\
5.54\end{array}$ & 5.29 & $\begin{array}{l}115.86 \\
112.41\end{array}$ & $\begin{array}{l}0.75 \\
0.74\end{array}$ & 0.74 \\
\hline 2 & $\begin{array}{l}\text { A } \\
\text { B }\end{array}$ & $\begin{array}{l}86.47 \\
87.24\end{array}$ & $\begin{array}{l}82.26 \\
83.07\end{array}$ & $\begin{array}{l}5.11 \\
5.01\end{array}$ & 5.06 & $\begin{array}{l}109.52 \\
111.67\end{array}$ & $\begin{array}{l}0.78 \\
0.78\end{array}$ & 0.78 \\
\hline 3 & $\begin{array}{l}\text { A } \\
\text { B }\end{array}$ & $\begin{array}{c}91.1 \\
90.71\end{array}$ & $\begin{array}{l}86.75 \\
86.30\end{array}$ & $\begin{array}{l}5.01 \\
5.11\end{array}$ & 5.06 & $\begin{array}{l}118.77 \\
118.11\end{array}$ & $\begin{array}{l}0.76 \\
0.76\end{array}$ & 0.76 \\
\hline 4 & $\begin{array}{l}\text { A } \\
\text { B }\end{array}$ & $\begin{array}{l}96.05 \\
91.47\end{array}$ & $\begin{array}{l}91.47 \\
89.24\end{array}$ & $\begin{array}{l}5.00 \\
2.49\end{array}$ & 3.74 & $\begin{array}{l}111.52 \\
113.14\end{array}$ & $\begin{array}{l}0.86 \\
0.80\end{array}$ & 0.83 \\
\hline 5 & $\begin{array}{l}\text { A } \\
\text { B }\end{array}$ & $\begin{array}{l}86.09 \\
90.07\end{array}$ & $\begin{array}{l}81.76 \\
85.54\end{array}$ & $\begin{array}{l}5.29 \\
5.29\end{array}$ & 5.29 & $\begin{array}{l}117.18 \\
112.02\end{array}$ & $\begin{array}{l}0.73 \\
0.80\end{array}$ & 0.78 \\
\hline 6 & $\begin{array}{l}\text { A } \\
\text { B }\end{array}$ & $\begin{array}{l}87.17 \\
92.83\end{array}$ & $\begin{array}{l}83.14 \\
88.54\end{array}$ & $\begin{array}{l}4.84 \\
4.84\end{array}$ & 4.84 & $\begin{array}{l}120.16 \\
112.93\end{array}$ & $\begin{array}{l}0.72 \\
0.82\end{array}$ & 0.77 \\
\hline 7 & $\begin{array}{l}\mathrm{A} \\
\mathrm{B}\end{array}$ & $\begin{array}{l}87.45 \\
81.41\end{array}$ & $\begin{array}{l}83.13 \\
77.41\end{array}$ & $\begin{array}{l}5.19 \\
5.16\end{array}$ & 5.17 & $\begin{array}{l}117.02 \\
115.69\end{array}$ & $\begin{array}{l}0.74 \\
0.70\end{array}$ & 0.72 \\
\hline 8 & $\begin{array}{l}\text { A } \\
\text { B }\end{array}$ & $\begin{array}{l}79.55 \\
86.49\end{array}$ & $\begin{array}{l}75.75 \\
82.48\end{array}$ & $\begin{array}{l}5.01 \\
4.86\end{array}$ & 4.93 & $\begin{array}{c}109.80 \\
120\end{array}$ & $\begin{array}{l}0.72 \\
0.72\end{array}$ & 0.72 \\
\hline SD & & & & & 0.50 & & & 0.04 \\
\hline $\mathrm{CV}$ & & & & & 10.23 & & & 4.79 \\
\hline
\end{tabular}

$\mathrm{SD}=$ standard deviation, $\mathrm{CV}=$ coefficient of variance

Table 5 Water absorption (WA) of particleboards from Acacia catechu + Melia dubia at different resin content and pressure

\begin{tabular}{|c|c|c|c|c|c|c|c|c|}
\hline $\begin{array}{c}\text { Board } \\
\text { number }\end{array}$ & $\begin{array}{l}\text { Sample } \\
\text { number }\end{array}$ & $\begin{array}{c}\text { Initial } \\
\text { weight } \\
(\mathrm{gm})\end{array}$ & $\begin{array}{l}\text { Weight } \\
\text { after } 2 \mathrm{~h} \\
(\mathrm{gm})\end{array}$ & $\begin{array}{l}\text { Weight } \\
\text { after } 24 \mathrm{~h} \\
\quad(\mathrm{gm})\end{array}$ & $\begin{array}{c}\text { WA } \% \text { after } \\
2 \mathrm{~h}\end{array}$ & $\begin{array}{c}\text { WA\% } \\
\text { after } 2 \mathrm{~h} \\
\text { (average) }\end{array}$ & $\begin{array}{c}\text { WA } \% \text { after } \\
24 \mathrm{~h}\end{array}$ & $\begin{array}{c}\text { WA } \% \\
\text { after } 24 \mathrm{~h} \\
\text { (average) }\end{array}$ \\
\hline \multirow[t]{2}{*}{1} & A & 154 & 270 & 282 & 75.32 & 71.88 & 83.11 & 81.15 \\
\hline & B & 149 & 251 & 267 & 68.45 & & 79.19 & \\
\hline \multirow[t]{2}{*}{2} & A & 129 & 205 & 217 & 58.91 & 57.14 & 68.21 & 66.79 \\
\hline & B & 130 & 202 & 215 & 55.38 & & 65.38 & \\
\hline \multirow[t]{2}{*}{3} & A & 162 & 242 & 259 & 49.38 & 52.43 & 59.87 & 62.19 \\
\hline & B & 155 & 241 & 255 & 55.48 & & 64.51 & \\
\hline \multirow[t]{2}{*}{4} & A & 155 & 236 & 250 & 52.25 & 50.8 & 61.29 & 59.49 \\
\hline & B & 156 & 233 & 246 & 49.35 & & 57.69 & \\
\hline \multirow[t]{2}{*}{5} & A & 168 & 288 & 298 & 71.42 & 69.46 & 77.38 & 76.81 \\
\hline & B & 160 & 268 & 282 & 67.5 & & 76.25 & \\
\hline \multirow[t]{2}{*}{6} & A & 164 & 261 & 373 & 59.14 & 63.53 & 66.46 & 72.53 \\
\hline & B & 159 & 267 & 384 & 67.92 & & 78.61 & \\
\hline \multirow[t]{2}{*}{7} & A & 158 & 244 & 257 & 54.43 & 53.44 & 62.65 & 61.74 \\
\hline & B & 166 & 253 & 267 & 52.46 & & 60.84 & \\
\hline \multirow[t]{2}{*}{8} & A & 159 & 258 & 272 & 62.26 & 66.79 & 71.06 & 76.29 \\
\hline & B & 157 & 269 & 285 & 71.33 & & 81.52 & \\
\hline $\mathrm{SD}$ & & & & & & 8.27 & & 8.15 \\
\hline $\mathrm{COV}$ & & & & & & 13.63 & & 11.71 \\
\hline
\end{tabular}

$\mathrm{SD}=$ standard deviation, $\mathrm{CV}=$ coefficient of variance 
Table 6 Swelling percentage of particleboards from Acacia catechu + Melia dubia at different resin content and pressure

\begin{tabular}{|c|c|c|c|c|c|c|c|}
\hline \multirow{2}{*}{$\begin{array}{c}\text { Board } \\
\text { number }\end{array}$} & \multirow{2}{*}{$\begin{array}{l}\text { Sample } \\
\text { number }\end{array}$} & \multicolumn{6}{|c|}{ Swelling percentage } \\
\hline & & $\begin{array}{l}\text { Length } \\
(\mathrm{mm})\end{array}$ & $\begin{array}{l}\text { Length } \\
\text { average }\end{array}$ & $\begin{array}{l}\text { Width } \\
(\mathrm{mm})\end{array}$ & $\begin{array}{l}\text { Width } \\
\text { average }\end{array}$ & $\begin{array}{l}\text { Thickness } \\
(\mathrm{mm})\end{array}$ & $\begin{array}{c}\text { Thickness } \\
\text { average }\end{array}$ \\
\hline \multirow[t]{2}{*}{1} & A & 0.81 & 0.81 & 1.09 & 1.29 & 2.3 & 2.35 \\
\hline & B & 0.82 & & 1.49 & & 2.4 & \\
\hline \multirow[t]{2}{*}{2} & A & 0.54 & 0.57 & 0.54 & 0.93 & 2.0 & 2.0 \\
\hline & B & 0.61 & & 1.32 & & 2.0 & \\
\hline \multirow[t]{2}{*}{3} & A & 0.88 & 0.74 & 0.96 & 0.89 & 3.2 & 2.6 \\
\hline & B & 0.61 & & 0.82 & & 2.0 & \\
\hline \multirow[t]{2}{*}{4} & A & 0.47 & 0.91 & 1.9 & 1.19 & 2.4 & 2.5 \\
\hline & B & 1.36 & & 0.48 & & 2.6 & \\
\hline \multirow[t]{2}{*}{5} & A & 0.54 & 0.54 & 0.81 & 0.67 & 1.9 & 1.75 \\
\hline & B & 0.54 & & 0.54 & & 1.6 & \\
\hline \multirow[t]{2}{*}{6} & A & 0.63 & 0.62 & 0.57 & 0.55 & 0.3 & 1.95 \\
\hline & B & 0.61 & & 0.54 & & 3.6 & \\
\hline \multirow[t]{2}{*}{7} & A & 0.73 & 0.77 & 0.91 & 0.73 & 4.2 & 4.4 \\
\hline & B & 0.81 & & 0.56 & & 4.6 & \\
\hline \multirow[t]{2}{*}{8} & A & 0.79 & 0.45 & 0.82 & 0.76 & 3.1 & 3.1 \\
\hline & B & 0.71 & & 0.71 & & 3.1 & \\
\hline $\mathrm{SD}$ & & & 0.16 & & 0.26 & & 0.85 \\
\hline $\mathrm{CV}$ & & & 23.02 & & 29.15 & & 32.95 \\
\hline
\end{tabular}

$\mathrm{SD}=$ standard deviation, $\mathrm{CV}=$ coefficient of variance

Table 7 Swelling due to surface absorption of particleboards from Acacia catechu + Melia dubia at different resin content and pressure

\begin{tabular}{|c|c|c|c|c|c|c|}
\hline \multirow[b]{2}{*}{$\begin{array}{c}\text { Board } \\
\text { number }\end{array}$} & \multirow[b]{2}{*}{$\begin{array}{l}\text { Sample } \\
\text { number }\end{array}$} & \multirow{2}{*}{$\begin{array}{c}\begin{array}{c}\text { Initial } \\
\text { thickness }\end{array} \\
\begin{array}{c}\text { Average } \\
(\mathrm{mm})\end{array}\end{array}$} & \multirow{2}{*}{$\begin{array}{c}\text { Thickness } \\
\text { after } 2 \mathrm{~h} \\
\begin{array}{c}\text { Average } \\
(\mathrm{mm})\end{array}\end{array}$} & \multirow[b]{2}{*}{$\begin{array}{c}\text { Swelling after } \\
2 \mathrm{~h}(\mathrm{~mm})\end{array}$} & \multirow[b]{2}{*}{$\begin{array}{c}\text { Swelling \% } \\
\text { after } 2 \mathrm{~h}\end{array}$} & \multirow[b]{2}{*}{$\begin{array}{c}\text { Swelling \% } \\
\text { average }\end{array}$} \\
\hline & & & & & & \\
\hline \multirow[t]{2}{*}{1} & A & 9.35 & 11.4 & 2.05 & 20.5 & 19.5 \\
\hline & B & 8.92 & 10.7 & 1.85 & 18.5 & \\
\hline \multirow[t]{2}{*}{2} & A & 8.30 & 10.5 & 2.20 & 22.0 & 23 \\
\hline & B & 8.20 & 10.6 & 2.40 & 24.0 & \\
\hline \multirow[t]{2}{*}{3} & A & 9.45 & 11.6 & 2.20 & 22.0 & 21.01 \\
\hline & B & 8.27 & 10.3 & 2.03 & 20.03 & \\
\hline \multirow[t]{2}{*}{4} & A & 8.10 & 10.2 & 2.15 & 21.5 & 22 \\
\hline & B & 8.20 & 10.4 & 2.25 & 22.5 & \\
\hline \multirow[t]{2}{*}{5} & A & 9.60 & 11.5 & 1.90 & 19.0 & 17.25 \\
\hline & B & 9.65 & 11.2 & 1.55 & 15.5 & \\
\hline \multirow[t]{2}{*}{6} & A & 9.52 & 11.3 & 1.85 & 18.5 & 15.2 \\
\hline & B & 9.63 & 10.8 & 1.19 & 11.9 & \\
\hline \multirow[t]{2}{*}{7} & A & 8.30 & 10.7 & 2.40 & 24.0 & 27.5 \\
\hline & B & 8.37 & 11.7 & 3.10 & 31.0 & \\
\hline \multirow[t]{2}{*}{8} & A & 9.10 & 11.1 & 2.00 & 20.0 & 17.35 \\
\hline & B & 9.80 & 11.2 & 1.47 & 14.70 & \\
\hline SD & & & & & & 3.91 \\
\hline $\mathrm{CV}$ & & & & & & 19.23 \\
\hline
\end{tabular}

$\mathrm{SD}=$ standard deviation, $\mathrm{CV}=$ coefficient of variance 


\section{Moisture content and density of sample boards}

The mean value of moisture content of particleboards varied from $3.74 \%$ to $5.29 \%$. Board 1 and 5 showed the highest moisture content (\%) whereas board 4 showed the lowest. The mean value of density of particleboards varied from $0.72 \mathrm{~g} \mathrm{~cm}^{-3}$ to $0.83 \mathrm{~g} \mathrm{~cm}^{-3}$. The highest density was shown by board 4 whereas board 7 and 8 showed the lowest. Standard deviation of moisture content was 0.5 ; all blocks deviated 0.5 from the average value of moisture content. The value of coefficient of variation was 10.23 , showing that level of dispersion around the mean is $10.23 \%$. Similarly, standard deviation of density was 0.04 ; all blocks deviated 0.04 from the average value of density. The value of coefficient of variation was 4.79 , showing that level of dispersion around the mean was $4.79 \%$. The present findings were in agreement with Warmbier et al. (2013) who studied the effects of density and resin content on the mechanical properties of particleboards, where the core layer was made from willow, Salix viminalis. The modulus of elasticity (MOE), modulus of rupture (MOR), and internal bond (IB) of particleboards was investigated. The results showed that these properties increased with increasing board density and resin content, according to quadratic functions.

\section{Water absorption of sample boards}

Board 1 from A. catechu and M. dubia showed maximum water absorption, while board 4 showed minimum water absorption among all boards after 2 and $24 \mathrm{~h}$. Standard deviation of water absorption after $2 \mathrm{~h}$ was 8.27; all blocks deviated 8.27 from the average value of water absorption $(2 \mathrm{~h})$. The coefficient of variation was 13.63, showing that level of dispersion around the mean was $13.63 \%$. Similarly, standard deviation of water absorption after $24 \mathrm{~h}$ was 8.15; all blocks deviated 8.15 from the average value of water absorption $(24 \mathrm{~h})$. The value of coefficient of variation was 11.71 , showing that level of dispersion around the mean was $11.71 \%$. High water absorption in products is due to the inherent characteristic of oil palm being a hygroscopic material (Sulaiman et al. 2009).

\section{Linear expansion of sample boards}

In general swelling, board 8 from A. catechu showed $0.45 \%$ for length, board 6 showed $0.55 \%$ for width (linear swelling) and board 5 showed $15.29 \%$ for thickness swelling which is within the critical value for $2 \mathrm{~h}$ soaking (IS 3087:2005). As for other boards made from different resin content and pressure, the linear and thickness swelling values were quite high. Standard deviation of length was 0.16 ; all the blocks deviated 0.16 from the average value of length. The coefficient of variation was 23.02, showing that level of dispersion around the mean was $23.02 \%$. Similarly, standard deviation of width was 0.26 ; all blocks deviated 0.26 from the average value of width. The coefficient of variation was 29.15, showing that the level of dispersion around the mean was $29.15 \%$. Also, standard deviation of thickness was 0.85 ; all blocks deviated 0.85 from the average value of thickness. The coefficient of variation was 32.95 , showing that the level of dispersion around the mean was $32.95 \%$. Rahman et al. (2019) reported the properties of particleboard with 50: 50 ratio of Neolamarckia cadamba and Leucaena leucocephala, with melamine urea formaldehyde, at different resin contents (10, 12 and 14\%) and particle sizes $(1 \mathrm{~mm}, 2 \mathrm{~mm}$ and unscreened particle). The results showed that the particle board mechanical properties significantly improved with the increase in resin content and particle size. The thickness swelling value dropped as resin content increased, sowing better stability of the board.

\section{Surface swelling of sample boards}

In surface swelling, all the boards are above the critical value as per IS 3087:2005. Board 6 showed minimum swelling i.e. $15.2 \%$ while board 7 showed maximum swelling, that is $27.5 \%$ among all boards. Standard deviation of surface swelling is 3.91; all the block deviated 3.91 from the average value of surface swelling. The value of coefficient of variation is 19.23, showing that level of dispersion around the mean is $19.23 \%$. Lower thickness swelling values represented higher consistency between fibre stability and overlaying, and generally presented higher internal bonding values. The thickness of swelling in products could be due 
to the inherent characteristic of oil palm being a hygroscopic material (Sulaiman et al. 2009).

\section{Mechanical properties}

Mechanical properties i.e. static bending strength, perpendicular to surface and screw, and nail withdrawal strength of particleboards from A. catechu and M. dubia, with particles at different resin content and pressures are shown in Table 8, 9 and 10 respectively. Numbers 1 to 8 are different boards, whereas $\mathrm{A}$ and $\mathrm{B}$ are the replications.

Modulus of rupture (MOR) and modulus of elasticity (MOE) of sample boards

The MOR was the highest for board 2 $\left(13.81 \mathrm{~N} \mathrm{~mm}^{-2}\right)$ and MOE was the highest for board $3\left(1562.82 \mathrm{~N} \mathrm{~mm}^{-2}\right)$. Standard deviation of MOR was 1.86; all the blocks deviated 1.86 from the average value of MOR. The coefficient of variation was 16.03 , showing that the level of dispersion around the mean was $16.03 \%$. Similarly, standard deviation of MOE was 198.70; all blocks deviated 198.70 from the average value of length. The coefficient of variation was 15.29, showing that the level of dispersion around the mean was $15.29 \%$. Samples of board 5 and 6 did not pass the critical values of MOR and MOE, as per the requirements of IS 3087-2005. The type and the quality of resin determine the binding quality and performance of panels (Ratkha et al. 2012, Salari et al. 2013, Anisuzzaman et al. 2014). Increasing the resin content was the first choice to increase board strength. The MOE and MOR increased as the resin content increased. The particle board with $14 \%$ resin content had the highest MOE and MOR at $3520 \mathrm{MPa}$ and 28.6 MPa respectively.

\section{Screw withdrawal strength of sample boards}

Board 4, made from A. catechu and M. dubia showed maximum value $\left(218 \mathrm{~kg} \mathrm{~cm}^{-2}\right)$ for face, while board sample 2 showed maximum value (239 $\mathrm{kg} \mathrm{cm}^{-2}$ ) for edge in screw withdrawal resistance, respectively. Standard deviation of face was 17.30; all blocks deviated 17.30 from

Table 8 Static bending strength of particleboards from Acacia catechu + Melia dubia at different resin content and pressure

\begin{tabular}{|c|c|c|c|c|c|c|}
\hline $\begin{array}{c}\text { Board } \\
\text { number }\end{array}$ & $\begin{array}{l}\text { Sample } \\
\text { number }\end{array}$ & $\begin{array}{c}\text { Maximum } \\
\text { load } \\
(\mathrm{N})\end{array}$ & $\begin{array}{c}\text { MOR } \\
\left(\mathrm{N} \mathrm{mm}^{-2}\right)\end{array}$ & $\begin{array}{c}\text { MOR } \\
\text { average } \\
\left(\mathrm{N} \mathrm{mm}^{-2}\right)\end{array}$ & $\begin{array}{c}\mathrm{MOE} \\
\left(\mathrm{N} \mathrm{mm}^{-2}\right)\end{array}$ & $\begin{array}{c}\text { MOE } \\
\text { average } \\
\left(\mathrm{N} \mathrm{mm}^{-2}\right)\end{array}$ \\
\hline 1 & $\begin{array}{l}\mathrm{A} \\
\mathrm{B}\end{array}$ & $\begin{array}{l}259.50 \\
272.00\end{array}$ & $\begin{array}{l}12.54 \\
13.25\end{array}$ & 12.89 & $\begin{array}{l}1251.58 \\
1345.62\end{array}$ & 1298.71 \\
\hline 2 & $\begin{array}{l}\mathrm{A} \\
\mathrm{B}\end{array}$ & $\begin{array}{l}296.00 \\
285.00\end{array}$ & $\begin{array}{l}13.88 \\
13.75\end{array}$ & 13.81 & $\begin{array}{l}1411.65 \\
1403.96\end{array}$ & 1407.80 \\
\hline 3 & $\begin{array}{l}\text { A } \\
\text { B }\end{array}$ & $\begin{array}{l}299.00 \\
259.00\end{array}$ & $\begin{array}{l}14.43 \\
12.73\end{array}$ & 13.58 & $\begin{array}{l}1490.60 \\
1635.04\end{array}$ & 1562.82 \\
\hline 4 & $\begin{array}{l}\text { A } \\
\text { B }\end{array}$ & $\begin{array}{l}262.00 \\
276.00\end{array}$ & $\begin{array}{l}12.52 \\
12.89\end{array}$ & 12.70 & $\begin{array}{l}1294.23 \\
1606.97\end{array}$ & 1450.6 \\
\hline 5 & $\begin{array}{l}\text { A } \\
\text { B }\end{array}$ & $\begin{array}{l}202.00 \\
188.00\end{array}$ & $\begin{array}{l}9.44 \\
8.81\end{array}$ & 9.12 & $\begin{array}{l}982.56 \\
887.88\end{array}$ & 935.22 \\
\hline 6 & $\begin{array}{l}\text { A } \\
\text { B }\end{array}$ & $\begin{array}{c}210.5 \\
206.00\end{array}$ & $\begin{array}{l}9.98 \\
9.44\end{array}$ & 9.71 & $\begin{array}{l}1236.08 \\
1063.76\end{array}$ & 1149.92 \\
\hline 7 & $\begin{array}{l}\text { A } \\
\text { B }\end{array}$ & $\begin{array}{l}221.50 \\
221.50\end{array}$ & $\begin{array}{l}10.62 \\
10.62\end{array}$ & 10.62 & $\begin{array}{l}1201.40 \\
1201.40\end{array}$ & 1201.40 \\
\hline 8 & $\begin{array}{l}\text { A } \\
\text { B }\end{array}$ & $\begin{array}{l}214.00 \\
205.00\end{array}$ & $\begin{array}{l}10.52 \\
10.00\end{array}$ & 10.26 & $\begin{array}{l}1397.12 \\
1378.19\end{array}$ & 1387.65 \\
\hline $\begin{array}{l}\text { SD } \\
\text { CV }\end{array}$ & & & & $\begin{array}{c}1.86 \\
16.03\end{array}$ & & $\begin{array}{c}198.70 \\
15.29\end{array}$ \\
\hline
\end{tabular}

$\mathrm{SD}=$ standard deviation, $\mathrm{CV}=$ coefficient of variance, $\mathrm{MOR}=$ modulus of rupture, $\mathrm{MOE}=$ modulus of elasticity 
Table 9 Screw and nail withdrawal strength of particleboards from Acacia catechu + Melia dubia at different resin content and pressure

\begin{tabular}{|c|c|c|c|c|c|c|}
\hline \multirow{3}{*}{$\begin{array}{c}\text { Board } \\
\text { number }\end{array}$} & \multicolumn{6}{|c|}{ Withdrawal load $\left(\mathrm{kg} \mathrm{cm}^{-2}\right)$} \\
\hline & \multicolumn{3}{|c|}{ Face } & \multicolumn{3}{|c|}{ Edge } \\
\hline & Screw 1 & Screw 2 & Average & Screw 1 & Screw 2 & Average \\
\hline 1 & 183 & 212 & 197.5 & 213 & 229 & 221 \\
\hline 2 & 197 & 209 & 203 & 232 & 242 & 239 \\
\hline 3 & 209 & 196 & 202.5 & 179 & 209 & 194 \\
\hline 4 & 221 & 215 & 218 & 156 & 178 & 167 \\
\hline 5 & 198 & 223 & 210.5 & 216 & 220 & 218 \\
\hline 6 & 194 & 206 & 200 & 169 & 150 & 159.5 \\
\hline 7 & 167 & 162 & 164.5 & 167 & 158 & 162.5 \\
\hline 8 & 173 & 184 & 178.5 & 233 & 217 & 225 \\
\hline $\mathrm{SD}$ & & & 17.30 & & & 31.75 \\
\hline $\mathrm{CV}$ & & & 8.79 & & & 16.01 \\
\hline
\end{tabular}

$\mathrm{SD}=$ standard deviation, $\mathrm{CV}=$ coefficient of variance

Table 10 Tensile strength perpendicular to surface of particleboards from Acacia catechu + Melia dubia at different resin content and pressure

\begin{tabular}{ccccccccc}
\hline $\begin{array}{c}\text { Board } \\
\text { number }\end{array}$ & $\begin{array}{c}\text { Sample } \\
\text { number }\end{array}$ & $\begin{array}{c}\text { Length } \\
(\mathrm{mm})\end{array}$ & $\begin{array}{c}\text { Width } \\
(\mathrm{mm})\end{array}$ & $\begin{array}{c}\text { Area } \\
\left(\mathrm{mm}^{2}\right)\end{array}$ & $\begin{array}{c}\text { Load } \\
(\mathrm{kg})\end{array}$ & $\begin{array}{c}\text { Load } \\
(\mathrm{N})\end{array}$ & $\begin{array}{c}\text { Tensile } \\
\text { strength } \\
\left(\mathrm{N} \mathrm{mm}^{-2}\right)\end{array}$ & $\begin{array}{c}\text { Average } \\
\text { tensile }\end{array}$ \\
\hline 1 & $\mathrm{~A}$ & 50 & 49.7 & 2485 & 242 & 2371.6 & 0.954 & 0.90 \\
& $\mathrm{~B}$ & 49.6 & 50 & 2480 & 217 & 2126.6 & 0.857 & \\
2 & $\mathrm{~A}$ & 50 & 50 & 2500 & 268 & 2626.4 & 1.050 & 1.11 \\
& $\mathrm{~B}$ & 49.7 & 49.6 & 2465.1 & 296 & 2900.8 & 1.176 & \\
3 & $\mathrm{~A}$ & 49.4 & 50 & 2470 & 312 & 3057 & 1.237 & 1.21 \\
& $\mathrm{~B}$ & 49.5 & 49.6 & 2455.2 & 298 & 2920.4 & 1.189 & \\
4 & $\mathrm{~A}$ & 50 & 49.3 & 2465 & 255 & 2499 & 1.013 & 0.99 \\
& $\mathrm{~B}$ & 49.9 & 49.8 & 2485.2 & 248 & 2430.4 & 0.977 & \\
5 & $\mathrm{~A}$ & 49.7 & 49.9 & 2480.03 & 265 & 2597 & 1.047 & 1.00 \\
& $\mathrm{~B}$ & 49.6 & 50 & 2480 & 246 & 2410.8 & 0.972 & \\
& $\mathrm{~A}$ & 49.6 & 49.6 & 2460.16 & 253 & 2479.4 & 1.007 & 0.98 \\
& $\mathrm{~B}$ & 49.4 & 50 & 2470 & 246 & 2410.8 & 0.976 & \\
7 & $\mathrm{~A}$ & 49.5 & 49.6 & 2455.2 & 264 & 2587.2 & 1.053 & 1.028 \\
& $\mathrm{~B}$ & 50 & 50 & 2500 & 256 & 2508.8 & 1.003 & \\
8 & $\mathrm{~A}$ & 49.2 & 49.6 & 2440.3 & 241 & 2361.8 & 0.967 & 0.99 \\
& $\mathrm{~B}$ & 50 & 49.3 & 2465 & 255 & 2499 & 1.013 & \\
SD & & & & & & & & 0.09 \\
CV & & & & & & & & 9.19 \\
\hline
\end{tabular}

$\mathrm{SD}=$ standard deviation, $\mathrm{CV}=$ coefficient of variance 
Table 11 Physical properties of particleboards from Acacia catechu + Melia dubia at different resin content and pressure

\begin{tabular}{ccccccc}
\hline \multirow{2}{*}{$\begin{array}{c}\text { Board } \\
\text { number }\end{array}$} & Moisture & Density & \multicolumn{2}{c}{ Parameters } \\
\cline { 2 - 5 } & \begin{tabular}{c} 
Wontent \\
\cline { 3 - 6 }
\end{tabular} & & $2 \mathrm{~h}$ & $24 \mathrm{~h}$ & $\begin{array}{c}\text { Thickness } \\
\text { swelling } \\
(\mathrm{mm})\end{array}$ & $\begin{array}{c}\text { Surface } \\
\text { swelling } \\
(\%)\end{array}$ \\
\hline 1 & 5.29 & 0.74 & 71.88 & 81.15 & 2.35 & 19.5 \\
2 & 5.06 & 0.78 & 57.14 & 66.79 & 2.0 & 23.0 \\
3 & 5.06 & 0.76 & 52.43 & 62.19 & 2.6 & 21.01 \\
4 & 3.74 & 0.83 & 50.80 & 59.49 & 2.5 & 22.0 \\
5 & 5.29 & 0.78 & 69.46 & 76.81 & 1.75 & 17.25 \\
7 & 4.84 & 0.77 & 63.53 & 72.53 & 1.95 & 15.20 \\
8 & 5.17 & 0.72 & 53.44 & 61.74 & 4.4 & 27.5 \\
\hline
\end{tabular}

Table 12 Mechanical properties of particleboards from Acacia catechu + Melia dubia at different resin content and pressure

\begin{tabular}{cccccc}
\hline $\begin{array}{c}\text { Board } \\
\text { number }\end{array}$ & $\begin{array}{c}\text { MOR } \\
\left(\mathrm{N} \mathrm{mm}^{-2}\right)\end{array}$ & $\begin{array}{c}\text { MOE } \\
\left(\mathrm{N} \mathrm{mm}^{-2}\right)\end{array}$ & \multicolumn{2}{c}{ Screw withdrawal test $(\mathrm{N})$} & Face \\
\hline A & 12.89 & 1298.71 & 197.5 & 221 & $\begin{array}{c}\text { Internal bonding / tensile } \\
\text { strength }\end{array}$ \\
B & 13.81 & 1407.80 & 203 & 239 & 0.90 \\
C & 13.58 & 1562.82 & 202.5 & 194 & 1.11 \\
D & 12.70 & 1450.60 & 218 & 167 & 1.21 \\
E & 9.12 & 935.22 & 210.5 & 218 & 0.99 \\
F & 9.71 & 1149.22 & 200 & 159.5 & 1.00 \\
G & 10.62 & 1201.40 & 164.5 & 162.5 & 0.98 \\
H & 10.26 & 1387.65 & 178.5 & 225 & 1.02 \\
\hline
\end{tabular}

MOR $=$ modulus of rupture, $\mathrm{MOE}=$ modulus of elasticity

the average of face. The coefficient of variation was 8.79 , showing that the level of dispersion around the mean was $8.79 \%$. Similarly, standard deviation of edge was 31.75 ; all blocks deviated 31.75 from the average of edge. The value of coefficient of variation was 16.01 , showing that the level of dispersion around the mean was $16.01 \%$. Flexural strength, screw and nail withdrawal resistance, and impact strength of wood plastic composites declined with the increase in fibre content from 60 to $80 \%$. This was attributed to the lack of compatibility between the phases (Chaharmahali et al. 2008).

\section{Tensile strength of sample boards}

Internal bond strength depends on particle and interaction with adhesive. In internal bonding, board 3 showed $1.27 \mathrm{~N} \mathrm{~mm}^{-2}$ which was the maximum obtained among all the boards. Furthermore, internal bond strength decreased in boards prepared with $12 \%$ resin content. Standard deviation of tensile strength was 0.09 ; all blocks deviated 0.09 from the average value of tensile strength. The coefficient of variation was 9.19 , showing that level of dispersion around the mean was $9.19 \%$. All other boards met the minimum requirement as per the specification of IS.3087:2005. A similar study was conducted by Prakash et al. (2017), where particle boards were tested for their physical and mechanical properties according to procedures defined in IS 3087-2005. The test results indicated that the particleboard made using the lops and tops of M. dubia confirmed to the requirements of IS 3087: 2005, grade II particle board of wood 
and other lignocelluloses materials for general purpose.

\section{CONCLUSION}

The results showed that the most suitable particleboard can be prepared by mixing particles of $A$. catechu and M. dubia in the ratio of 50:50 with $12 \%$ resin content at $21 \mathrm{~kg} \mathrm{~cm}^{-2}$ specific pressure and $150{ }^{\circ} \mathrm{C}$ temperature for 15 minutes, which meets most requirements of medium density particle board as per the Indian Standard (IS 3087:2005), i.e., MOR and tensile strength perpendicular to the grain (internal bond). However, some mechanical properties such as MOE and screw holding strength was low. Some physical properties like water absorption and swelling due to surface were slightly higher, which can be reduced by adding suitable additives at the time of board preparation. Further detailed studies on the utilisation of kattha extracted particles of A. catechu and M. dubia, for the development of particle boards and wood composites, are needed.

\section{ACKNOWLEDGMENTS}

The authors would like to acknowledge their colleagues at the Forest Research Institute (FRI) for providing the human resources necessary for the project. With great pleasure, the authors would like to thank Negi A., Directorate of Education, ICFRE; Dehradun for extending his impeccable guidance. The authors also express their sincere thanks and personal regards to laboratory staff for their support and help during the project.

\section{REFERENCES}

Alam Nazmul DM, Khandkar-Siddikur Rahman, Sourav Bagchi Ratul, Arifa Sharmin, Tania Islam, Md. Abu Wabaeid Hasan \& Md. Nazrul Islam. 2015. Properties of particleboard manufactured from commonly used bamboo (Bambusa vulgaris) wastes in Bangladesh. Advances in Research 4: 203-211.

Anisuzzaman SM, Bono A, Krishnaiah D, Noor Maizara I \& Mansuit H. 2014. The performance of melamine urea-formaldehyde (MUF) based particleboard with wheat flour as filler. Jurnal Teknologi 68: 61-69.

Chaharmahali Majid, Mehdi Tajvidi \& Saeed Kazemi Najafi. 2008. Mechanical properties of wood plastic composite panels made from waste fibreboard and particleboard. Polymer composites 29: 606-610.
Choudhary CL, Negi A, Yadav SM \& Sihag K. 1915. Role of resin content in the manufacturing of particleboard from mixed plantation species. International Journal on Biological Sciences 6: 132-135.

Gomez KA \& Gomez AA. 1984. Statistical Procedure for Agricultural Research. $2^{\text {nd }}$ edition. Willey Interscience, New York.

ISI. 1962. Indian Council of Forestry Research and Education, Dehradun. Khair (Acacia catechu). Forest Research Institute, Dehradun.

Iwakiri S, Matos JL, MD, Trianoski R \& Prata JG. 2012. Production of homogeneous and multilayer particleboard from Melia azedarach (Cinamomo) and Pinus taeda with different resin contents. Cerne 18: 465-470.

Mayuree D. 1990. Properties of medium-density fibreboard manufactured from extracted and unextracted Acacia Catechu wood chips. PhD thesis. University Pertanian Malaysia, Serdang.

Nasser RA. 2012. Physical and mechanical properties of three-layer particleboard manufactured from the tree pruning of seven wood species. World Applied Sciences Journal. 19: 741-753.

Prakash V, Uday DN, Sujatha D \& Kiran MC. 2017. Physical and mechanical properties of particle board from lops and tops of Melia dubia. International Journal of Science and Research 6: 1499-1502.

Rahim-Sudin \& Wan-Asma-IBrahim. 1990. Journal of Tropical Forest Science 2: 267-273.

Rahman WMNWA, Yatim AAMd, Zln AAM, Kasim J \& Yunus NYM (2019). Effect of resin content and particle size on the properties of particleboard made of Neolamarkia and Leucaena particles. BioResources 14: 6079-6087.

Ratkhe J, Sinn G, Harm H, Teischinger A, Weigl M \& Muller U (2012). Effects of alternative raw materials and varying resin content on mechanical and fracture mechanical properties of particleboards. BioResources 7: 2970-2985.

Hegazy S \& Ibrahim MA. 2010. Suitability of some fast-growing trees and date palm fronds for particleboard production. Forest Products Journal 60: 599-604.

Saini G, Bhardwaj R, Choudhary V \& Narula AK. 2010. Poly (vinyl chloride)-Acacia bark flour composite: Effect of particle size content on mechanical, thermal and morphological characteristics. Journal of Applied Polymer Science 117: 1309-1318.

Salari A, Tabarsa T, Khazaeian A \& Saraeian A. 2013. Improving some of the applied properties of oriented strand board (OSD) made from underutilised low-quality paulownias (Paulownia fortunie) wood employing nano-SiO ${ }_{2}$. Industrial Crop and Products. 42: 1-9.

Siva R. 2007. Status of natural dyes and dye-yielding plants in India. Current Science: 916-925.

Sulaiman O, Salim N, Hashim R, Yusof LHM, Razak W \& Yunus NYM. 2009. Evaluation of the suitability of some adhesives for laminated veneer lumber from oil palm trunks. Material Design 30: 35723580. 
TeWari DN. 1994. A Monograph on Khair (Acacia catechu Wild). International Book Distributors, Dehradun. TEWARI DN. 1995. A Monograph on Khair (Acacia catechu Wild). International Book Distributors, Dehradun.

Uday DN, Sujatha D \& Pandey CN. 2011. Suitability of Melia dubia for plywood manufacture. Journal of the Indian Academy and Wood Science 8: 207.
Warmbier K, Wilczynski A \& Danecki L. 2013. Effects of density and resin content on mechanical properties of particleboards with the core layer made from willow Salix viminalis. Annals of Warsaw University of Life Sciences - SGGW. Forestry and Wood Technology 84: 284-287. 